\title{
Implementasi Pengoperasian Bus Trans Mataram Metro Di Kota Mataram (Studi Kasus Di Dinas Perhubungan Kota Mataram)
}

\author{
Mustamin H. Idris', M. Ulfatul Akbar ${ }^{2}$, Fauzy As Syafiq ${ }^{3}$ \\ ${ }^{1}$ Prodi Administrasi Publik, Universitas Muhammadiyah Mataram, Indonesia \\ ${ }^{2}$ Prodi Administrasi Publik, Universitas Muhammadiyah Mataram, Indonesia \\ ${ }^{3}$ Prodi Administrasi Publik, Universitas Muhammadiyah Mataram, Indonesia
}

\section{INFO ARTIKEL}

Riwayat Artikel:

Diterima: 8-08-2019

Disetujui: 30-08-2019

\section{Kata Kunci:}

1. Implementasi

2. Pengoperasian

3. Bus Trans

4. Kota Mataram

\section{ABSTRAK}

Abstrak: Penelitian ini dilatarbelakangi oleh permasalahan kemacetan transportasi perkotaan yang diakibatkan tingginya jumlah kendaraan dari para pengguna alat transportasi itu sendiri. Menanggapi permasalahan tersebut Kementerian Perhubungan mencanangkan program pengembangan angkutan umum berbasis jalan salah satunya pengadaan Bus Rapid Transit (BRT) untuk wilayah Kota Mataram dan sekitarnya. BRT Kota Mataram yang disebut juga Bus Trans Mataram merupakan salah satu jenis model angkutan umum yang efisien, aman, nyaman dan terjangkau dengan daya beli masyarakat. Bus Trans Mataram ini mulai beroperasi pada tanggal 21 November 2016 yang memiliki 4 rute. Pertama, di dalam kota, kedua dari pinggiran timur kota, ketiga dari pinggiran utara kota dan keempat, sayang-sayang hingga jalan Lingkar Selatan.

Penelitian ini menggunakan metode kualitatif. Penelitian Kualitatif merupakan penelitian yang bertujuan untuk menggambarkan dan mendeskripsikan peristiwa maupun fenomena yang terjadi di lapangan dan menyajikan data secara sistematis, faktual, dan akurat mengenai fakta-fakta atau fenomena yang terjadi di lapangan. Pengumpulan data dilakukan dengan Teknik Observasi, Wawancara, dan Dokumentasi. Peneliti menggunakan Triangulasi sumber untuk mengecek keabsahan data penelitian. Analisis data dalam penelitian ini menggunakan tiga komponen yang terdiri dari Reduksi data, Penyajian data, dan Penarikan kesimpulan.

Hasil penelitian yang dilakukan ini menunjukan bahwa implementasi kebijakan pengoperasian bus Trans Mataram Metro di Kota Mataram belum berjalan secara efektif. Hal ini berdasarkan dari kurangnya sosialisasi, tidak konsistennya implementor, tidak adanya ketegasan pemerintah daerah, tidak tersedianya anggaran operasional yang memadai dalam mengimplementasikan program, dibutuhkannya kontribusi dari Dishub Kota Mataram di bidang angkutan. Sedangkan untuk indikator, besarnya biaya yang dibutuhkan dalam pemenuhan biaya operasional, terjadi penurunan jumlah penumpang, dan masih terdapat ketidaksesuaian kualitaas pelayanan pada bus Trans Mataram Metro. Oleh karena harus adanya pembenahan dari lembaga-lembaga terkait mengenai pengoperasian Bus Trans Mataram Metro sehingga berjalan sesuai dengan rencana yang telah ditetapkan. 
Keyword:

1. Implementation

2. Operation

3. Trans Bus

4. Mataram City

\section{Latar Belakang}

Negara berkembang adalah Negara yang pendapatan rata-ratanya rendah, infrastruktur relative berkembang, dan indeks perkembangan manusia berada di bawah standar normal global. Kelompok Negara berkembang ini memiliki pembangunan sosial terbelakang yang tampak pada rendahnya kualitas sumber daya manusia, seperti rendahnya usia harapan hidup, tingginya kematian bayi dan anak.

Permasalahan pembangunan yang ada di negara berkembang masih belum berjalan secara maksimal. Pendapatan penduduk di sektor swasta dan juga pemerintah masih tergolong rendah. Tidak hanya itu, daya saing negara berkembang di pasar Internasional juga rendah. Sektor swasta maupun pemerintahan memiliki tabungan yang minim dan tingginya utang kepada pihak luar negeri. Finansial

\section{Abstract} congestion caused by the high number of vehicles of the users of the transportation itself. Responding to the problem, the Ministry of Transportation has launched a road-based public transportation development program, one of which is the provision of Bus Rapid Transit (BRT) for the City of Mataram and surrounding areas. The Mataram City BRT, also called the Trans Mataram Bus, is one of the types of public mortation models that is efficient, safe, comfortable and affordable unfortunately to the South Ring Road.

research that aims to describe and describe events and phenomena that occur in the field and present data systematically, factually, and accurately about facts or phenomena that occur in the field. Data collection is done by Observation, Interview, and Documentation Techniques. Researchers use source triangulation to check the validity of research data. Data analysis in this study used three components consisting of data reduction, data presentation, and drawing conclusions.

The results of this research indicate that the implementation of Trans Mataram Metro bus operating policies in Mataram City has not been effective. This is based on the lack of socialization, the inconsistency of the implementor, the lack of firmness of the local government, the unavailability of an adequate operational budget in implementing the program, the need for contributions from the Transportation Department of Mataram in the field of transportation. As for the indicators, the amount passengers, and there are still mismatches of service quality on the Trans Mataram Metro bus. Therefore there must be improvements from relevant institutions regarding the operation of the Trans Mataram Metro Bus so that it runs according to the plan that has been set.

pemerintah maupun swasta bergantung pada pinjaman asing, investasi swasta dari luar dan juga bantuan dari negara lain. Negara berkembang secara sengaja membatasi pengeluaran untuk sektor sosial sebab dana dialokasikan ke sektor lain yang dirasa lebih penting. Misalnya infrastruktur ataupun pendidikan. Bahkan negara tertentu tidak menyediakan jaminan sosial bagi penduduk yang cacat, hamil, pengangguran, sakit, dan mati.

Indonesia sebagai negara berkembang sedang mengalami pertumbuhan ekonomi. Berdasarkan data dari BPS, pada kuartal II tahun 2016 pertumbuhan ekonomi Indonesia mencapai 5.18\%. Dari segi fisik, indikasi adanya pertumbuhan ekonomi terutama di daerah urban adalah tingginya intensitas pergerakan masyarakat. Hal ini membuat bidang transportasi menjadi perhatian turunan yang artinya kebutuhan terhadap transportasi berasal dari kebutuhan terhadap pergerakan masyarakatnya. 
Tingginya pergerakan masyarakat menunjukan tingginya aktivitas ekonomi. Pergerakan bisa dilihat dari adanya perpindahan masyarakat untuk bekerja, sekolah, melakukan distribusi barang logistik, dll. Di daerah urban sistem pergerakan ini begitu kompleks. Banyaknya commuters, shoppers dan pelajar yang memerlukan pergerakan ke kawasan tujuannya membentuk sistem jaringan pergerakan dengan pola sendiri.

Di negara-negara berkembang, permasalahan kemacetan sendiri disebabkan oleh banyak hal. Pendapatan rendah, urbanisasi yang sangat cepat, terbatasnya sumber daya, khususnya dana, kualitas dan kuantitas data yang berkaitan dengan transportasi, kualitas sumber daya manusia, tingkat disiplin yang rendah, dan lemahnya sistem perencanaan dan kontrol membuat permasalahan transportasi menjadi semakin parah (Ofyar Z Tamin: 2000).

Transportasi merupakan urat nadi Pembangunan Nasioanal untuk melancarakan arus manusia barang maupun informasi. Sebagai alat penunjang tercapainya pengalokasian sumbersumber perekonomian secara optimal. Untuk itu jasa transportasi harus cukup tersedia secara merata dan terjangkau daya beli masyarakat. Transportasi yang banyak digunakan oleh masyarakat di Indonesia adalah salah satunya transportasi darat. Pertambahan penduduk dan luas kota menyebabkan jumlah lalu lintas juga meningkat. Sedangkan sistem lalu lintas mendekati jenuh, sehingga bertambahnya jumlah lalu lintas berpengaruh besar terhadap lingkungan.

Akan tetapi dalam realitasnya, permasalahan kemacetan akibat banyaknya jumlah alat transportasi darat ini masih terjadi dalam kategori yang memprihatinkan. Mengurai lebih dalam mengenai sebuah permasalahan kemacetan di kotakota besar Indonesia tidak akan terlepas dari para pengguna alat transportasi darat itu sendiri. Dalam hal ini masyarakat di kota-kota besar menjadi target utama di dalam usaha mencoba memahami kemacetan terkait akibat tingginya jumlah kendaraan.

Permasalahan transportasi perkotaan tidak akan pernah lepas dari masalah kemacetan, permasalahan yang jamak terjadi utamanya pada kota-kota besar. Permasalahan ini pun nampaknya mulai terjadi di Kota Mataram. Perkembangan Kota Mataram yang berimbas pada peningkatan ekonomi dan kesejahteraan masyarakat telah merubah pola kegiatan yang mengakibatkan meningkatnya mobilitas masyarakat. Kita rasakan sendiri, kondisi lalu lintas Kota Mataram yang semakin padat beberapa tahun terakhir khususnya pada jam-jam sibuk yaitu pada pagi, siang dan sore hari khsusunya pada jam-jam kerja dan sekolah. Dapat dipastikan kondisi tersebut akan semakin sering kita rasakan dan bahkan akan mencapai puncaknya apabila tidak dapat tertangani dengan baik.

Pelayanan angkutan umum di Kota Mataram saat ini berada dalam kondisi yang cukup memprihatinkan. Namun bila ditinjau dari aktivitas pergerakkan didalam kota saat ini, Kota Mataram sebagai ibu kota provinsi NTB menunjukkan bangkitan perjalanan yang tinggi dibandingkan dengan kota-kota disekitarnya. Kondisi seperti ini untuk suatu kota besar lazimnya membutuhkan suatu layanan angkutan umum yang handal untuk mengakomodasi kebutuhan mobilitas penduduk yang juga mendukung pertumbuhan ekonomi kota. Saat ini hanya terdapat 2 trayek angkutan umum yang beroperasi di Kota Mataram yang kinerja layanannya sudah sangat jauh menurun. Mengacu pada laporan DED Interkoneksi Angkutan Umum Trans Mataram Metro, rata-rata faktor muat (load factor) harian angkutan kota yang beroperasi kurang dari $46 \%$ dan cenderung menuju kondisi berhenti operasi (collapse). Situasi inilah yang melatar belakangi masyarakat untuk lebih memilih menggunakan kendaraan pribadi baik sepeda motor maupun mobil pribadi selain dari kemudahan dalam memiliki dan mengoperasikan. Kondisi seperti ini untuk suatu kota besar lazimnya membutuhkan suatu layanan angkutan umum yang handal untuk mengakomodasi kebutuhan mobilitas penduduk yang juga mendukung pertumbuhan ekonomi kota (Sufiani et al: 2016).

Menanggapi permasalahan tersebut Kementerian Perhubungan mencanangkan program pengembangan angkutan umum berbasis jalan di wilayah perkotaan. Salah satu dari realisasi program tersebut adalah pengadaan Bus Rapid Transit (BRT) untuk wilayah Kota Mataram dan sekitarnya. BRT Kota Mataram disebut juga dengan bus Trans Mataram Metro. BRT merupakan salah satu jenis model angkutan umum yang efisien, aman, nyaman dan terjangkau oleh daya beli masyarakat. Pemerintah berharap dengan adanya BRT dapat meningkatkan daya tarik masyarakat untuk menggunakan angkutan umum sehingga dapat menekan penggunaan kendaraan pribadi.

Bus Trans Mataram Metro merupakan suatu sistem transportasi bus cepat, murah, dan ber AC di kawasan Kota Mataram. Bus ini merupakan salah satu bagian dari program penerapan Bus Rapid Transit (BRT). Motto pelayanan bus Trans Mataram Metro adalah "Aman, Nyaman, Andal, Terjangkau, 
dan Ramah Lingkungan”. Landasan kebijakan Bus Trans Mataram Metro ini sendiri adalah Undangundang Nomor 22 tahun 2009 tentang angkutan jalan dan lalu lintas.

Bus Trans Mataram Metro ini mulai beroperasi pada tahun 2016, tepatnya pada tanggal 21 November 2016, bus Mataram Metro memiliki ukuran yang hampir sama dengan bus-bus pada umumnya, perbedaannya adalah pada bus Trans Mataram Metro ini menerapkan sistem murah dimana para penumpang umum dikenakan tarif jauh-dekat sebesar 4000 per orang. Selain itu, tempat duduk yang berhadapan dan memanjang, memiliki daya tampung penumpang di masingmasing busnya sebanyak 75 orang dan di dalam bus menggunakan air conditioner (AC) yang membuat penumpang tidak kepanasan seperti di bus-bus kota pada umumnya. Bus Trans Mataram Metro sendiri memiliki 4 rute. Pertama, di dalam kota, kedua dari pinggiran timur kota, yaitu Narmada-SelagalasSenggigi. Ketiga, dari pinggiran utara kota, yaitu Gunung Sari-Udayana hingga Banyu Mulek di selatan. Keempat, Sayang-sayang-Gegutu-Jalan Bung Karno-Bung Hatta hingga Jalan Lingkar Selatan.

Berdasarkan permasalahan tersebut diatas, peneliti merasa tertarik dan bermaksud untuk mengadakan penelitian lebih lanjut yang dituangkan dalam bentuk usulan penelitian dengan judul: "Implementasi Kebijakan Pengoperasian Bus Trans Mataram Metro di Kota Mataram (Studi Kasus Di Dinas Perhubungan Kota Mataram )"

\section{Tinjauan Pustaka}

\section{a. Kebijakan Perencanaan Angkutan Massal}

Dalam menyempurnakan proposal ini, Berikut teori-teori yang dikutip dari penelitian-penelitian terdahulu:

a. Angkutan Umum Penumpang di Kota Mataram biasa disebut bemo adalah salah satu sarana transportasi yang digunakan untuk melayani aktivitas masyaraat di Kota Mataram. Berdasarkan keputusan Walikota Mataram No: 14/KPTS/2000 tentang penetapan lintasan trayek angkutan umum penumpang dalam jaringan trayek Kota Mataram, terdapat 13 jaringan trayek untuk pelayanan penumpang, yang terdiri dari 2 trayek utama dengan jumlah armada 388 unit, 3 trayek cabang 10 unit, dan 8 trayek ranting 39 unit. Dari 13 jaringan trayek tersebut yang masih beroperasi sampai saat ini hanya angkutan umum penumpang rute SwetaAmpenan. Berdasarkan Peraturan Walikota Mataram No: 17 Tahun 2013 tentang tarif angkutan umum penumpang jauh-dekat adalah Rp. 4000 untuk penumpang umum dan Rp. 3000 untuk penumpang pelajar berseragam (Yuliana et al, 2014:130)

b. Menurut Warpani dalam Yuliana (2014:132), pengadaan pelayanan AUP memang secara langsung mengurangi banyaknya kendaraan pribadi, namun AUP bukan salah satu jalan keluar untuk menyelesaikan masalah lalu-lintas kota. Pelayanan AUP akan berjalan dengan baik apabila tercipta keseimbangan antara penyediaan dan permintaan. Dalam hal ini partisipasi pemerintah sangat diperlukan dengan tujuan: (a) Menjamin sistem operasi yang sama bagi kepentingan masyarakat pengguna jasa angkutan, petugas pengelola angkutan dan pengusaha jasa angkutan. (b) Mengarahkan agar lingkungan tidak terlalu terganggu kegiatan angkutan. (c) Menciptakan persaingan sehat dan menghindarkan kembaran yang tidak perlu. (d) Membantu perkembangan dan pembangunan nasional maupun daerah dengan meningkatkan pelayanan jasa angkutan. (e) Menjamin pemerataan jasa angkutan sehingga tidak ada pihak yang dirugikan. (f) Mengendalikan operasi pelayanan jasa angkutan.

c. Definisi world bank dalam Rudor et al (2012:161) menyatakan konseptual, sustainable transportation adalah transportasi yang melayani tujuan utama sebagai penggerak ekonomi wilayah perkotaan dan perkembangan sosial. Poin penting dalam sustainable transportation, yaitu:

1) Kegiatan transportasi yang mengutamakan keselamatan dan kenyaman pemakai atau masyarakat. Hal ini mengingat jalan ataupun infrastruktur transportasi lainnya dibuat untuk manusia bukan untuk kendaraan. Jadi kenyamanan manusia umum harus diutamakan.

2) Semua kegiatan transportasi harus dilakukan secara efisien dan efektif baik untuk pemakai kendarannya ataupun bahan bakar yang digunakan. Selama ini kendaraan pribadi ratarata setiap harinya hanya berisi satu orang. Jadi jika satu orang itu dialihkan untuk menggunakan kendaraan umum, maka bisa dibayangkan berapa banyak bahan bakar yang akan tersimpan dan berapa banyak kemacetan dan emisi kendaraan yang akan berkurang.

3) Tiga pilar penting transportasi, yaitu ekologi, ekonomi dan sosial harus seimbang. Kegiatan transportasi dalam konsep sustainable transportation harus bisa menyeimbangkan semua aspek tersebut. 
4) Trasnportasi bukan hanya bisa dinikmati masa sekarang, namun juga untuk masa yang akan datang.

5) Penggunaan transportasi yang ramah lingkungan.

d. Menurut Peraturan Daerah Kota Mataram Nomor 7 Tahun 2014 Tentang Penyelenggara Perhubungan adalah (1) Bhwa untuk menunjang perkembangan pembangunan, mendorong pertumbuhan perekonomian, dan peningkatan kesejahteraan masyarakat, serta untuk mengatasi permasalahan kemacetan dan pengendalian kecelakaan lalu lintas di daerah, diperlukan perbaikan system Lalu Lintas dan Angkutan jalan yang menjamin keselamatan, kelancaran, ketertiban, keamanan dan kenyamanan, serta berwawasan lingkungan. (2) Bahwa penyelenggaraan perhubungan perlu diintegrasikan dengan system Lalu Lintas dan Angkutan Jalan ke dalam satu kebijakan Pemerintah Daerah melalui penataan system transportasi perkotaan yang berbasis pelayanan kepada masyarakat. (3) Bahwa sesuai dengan Undang-Undang Nomor 23 Tahun 2014 tentag Pemerintah Daerah, maka pemerintah daerah dapat melaksanakan penyelenggaraan perhubungan sesuai dengan kewenangannya.

\section{b. Pengertian Kebijakan Publik}

Terdapat banyak definisi mengenai apa yang maksud dengan kebijakan publik dalam literaturliteratur politik. Masing-masing definisi memberi penekanan yang berbeda-beda. Perbedaan ini timbul karena masing-masing para ahli mempunyai latar belakang yang berbeda-beda, walaupun pendekatan dan model yang digunakan oleh para ahli pada akhirnya juga akan dapat menentukan bagaimana kebijakan publik tersebut hendak didefinisikan.

Laswell dan Kaplan dalam Nugroho (2008:53) mendefinisikan kebijakan publik sebagai suatu program yang diproyeksikan dengan tujuan-tujuan tertentu, nilai- nilai tertentu, dan praktik-praktik tertentu. Sedangkan James Anderson dalam Islamy (2001:19) mengemukakan kebijakan publik sebagai kebijaksanaan-kebijaksanaan yang dikembangkan oleh badan-badan dan pejabat-pejabat pemerintah.

Sementara itu Dunn dalam Pasolong (2010:39), mengatakan kebijakan publik sebagai suatu rangkaian pilihan-pilihan yang saling berhubungan yang dibuat oleh lembaga atau pejabat pemerintah pada bidang-bidang yang menyangkut tugas pemerintahan, seperti pertahanan keamanan, energi, kesehatan, pendidikan, kesejahteraan masyarakat, kriminalitas, perekonomian dan lain-lain. Kemudian, secara lebih singkat, Thomas R. Dye dalam Santosa
(2009:27) merumuskan kebijakan sebagai pilihan pemerintah untuk bertindak atau tidak bertindak.

Dari beberapa definisi tersebut peneliti dapat menyimpulkan bahwa kebijakan publik merupakan serangkaian tindakan yang telah ditentukan oleh pemerintah (instansi publik) yang mempunyai tujuan untuk mengatur kepentingan seluruh anggota masyarakat.

\section{c. Tahap-Tahap Kebijakan Publik}

Charles Lindblom dalam Winarno (2007:32) mengemukakan bahwa proses pembuatan kebijakan public merupakan proses yang kompleks karena melibatkan banyak proses maupun variabel yang harus dikaji oleh actor pembuat kebijakan. Oleh karena itu, beberapa ahli politik yang menaruh minat untuk mengkaji kebijakan publik membagi proses-proses penyusunan kebijakan publik ke dalam beberapa tahap. Tujuan pembagian seperti ini adalah untuk memudahkan dalam mengkaji kebijakan publik. Tahap-tahap kebijakan publik yang dikemukakan oleh Dunn (1998:22) adalah sebagai berikut:

1. Tahap Penyusunan Agenda

Sejumlah aktor yang dipilih dan diangkat untuk merumuskan masalah-masalah pada agenda publik. Sebelumnya masalah-masalah ini berkompetisi terlebih dahulu untuk dapat masuk ke dalam agenda kebijakan, karena tidak semua masalahmenjadi prioritas dalam agenda kebijakan publik. Pada akhirnya, beberapa masalah masuk ke agenda kebijakan para perumus kebijakan. Pada tahap ini suatu masalah mungkin tidak disentuh sama sekali, sementara masalah lain ditetapkan menjadi fokus pembahasan, atau ada pula masalah karena alasan-alasan tertentu ditunda untuk waktu yang lama.

2. Tahap Formulasi Kebijakan

Masalah yang telah masuk ke agenda kebijakan kemudian dibahas oleh para actor pembuat kebijakan. Masalah-masalah tersebut kemudian didefinisikan untuk kemudian dicari solusi pemecahan masalah terbaik. Pemecahan masalah tersebut berasal dari berbagai alternative atau pilihan kebijakan (policy alternatives/policy options) yang ada. Sama halnya dengan perjuangan suatu masalah untuk masuk ke dalam agenda kebijakan, dalam tahap perumusan kebijakan masing-masing alternative bersaing untuk dapat dipilih sebagai tindakan yang diambil untuk memecahkan masalah. Pada tahap ini, masing-masing aktor akan "bermain" untuk mengusulkan pemecahan masalah tersebut. 
3. Tahap Adopsi Kebijakan

Berbagai macam alternatif kebijakan yang ditawarkan oleh para aktor perumus kebijakan, pada akhirnya salah satu dari alternative kebijakan tersebut diadopsi untuk tindakan lebih lanjut dalam kebijakan public dengan dukungan dari mayoritas legislatif, consensus antara direktur lembaga atau keputusan peradilan.

4. Tahap Implementasi Kebijakan

Suatu program kebijakan hanya akan menjadi catatan-catatan elit, jika program tersebut tidak diimplementasikan. Oleh karena itu, keputusan program kebijakan yang telah diambil sebagai alternative pemecahan masalah harus diimplementasikan, yakni dilaksanakan oleh badan-badan pemerintah di tingkat bawah. Kebijakan yang telah diambil dilaksanakan oleh badan-badan pemerintah yang memobilisasi sumberdaya finansial dan manusia. Pada tahap implementasi ini muncul berbagai kepentingan yang akan saling bersaing. Beberapa implementasi kebijakan mendapat dukungan para pelaksana (implementors), namun beberapa yang lain mungkin akan ditentang oleh para pelaksana.

5. Tahap Evaluasi Kebijakan

Pada tahap ini kebijakan yang telah dijalankan akan dinilai atau dievaluasi, hal ini dilakukan untuk melihat sejauh mana kebijakan yang dibuat telah mampu memecahkan masalah. Kebijakan public pada dasarnya dibuat untuk meraih dampak yang diinginkan. Dalam hal ini, memecahkan masalah yang dihadapi masyarakat. Oleh karena itu, ditentukanlah ukuran-ukuran atau kriteria-kriteria yang menjadi dasar untuk menilai apakah kebijakan public telah meraih dampak yang diinginkan.

Dilihat dari uraian di atas mengenai tahapan pembuatan kebijakan publik, maka dapat dimengerti bahwa dalam perumusan kebijakan public tidaklah mudah. Mengingat banyaknya masalah-masalah yang ada dalam masyarakat tentunya juga membutuhkan pemecahan masalah yang tepat dan sesuai untuk kondisi masyarakat yang ada. Oleh karena itu dalam menentukan kebijakan para aktor harus benar-benar mengkaji dengan tepat sehingga tidak merugikan masyarakat.

\section{d. Implementasi Kebijakan Publik}

Secara etimologis pengertian implementasi menurut Kamus Webster yang dikutip oleh Wahab (2004:64) adalah "to provide the means for carrying out (menyediakan sarana untuk melaksanakan sesuatu); dan to give practical effect to (untuk menimbulkan dampak/akibat terhadap sesuatu)".
Sementara Donald S. Van Metter dan Carl E. Va dalam Widodo (2010:86) memberikan pengertian implementasi dengan mengatakan:

Policy implementation encompasesses those action by public and private individual (or group) that are directed at the achievement of objectives set forth in prior policy decision. This include both one time efforts to transfrom decisions into operational terms, as well as continuing efforts to achieve the large and small changes mandated by policyyy decision

Dan Mazmanian dan Sabatier dalam Widodo (2010:87) menjelaskan makna implementasi dengan mengatakan:

To understand what actually happens after a program is enacted or formulated is the subject of policy implementation. Those event and activities that occur after the issuing of outhoritative public policy directives, wich included both the effort to administer and the subtantives, which impacts on the people and event

Sehingga Widodo (2010:88) memberikan kesimpulan pengertian bahwa:

Implementasi merupakan suatu proses yang melibatkan sejumlah sumber yang termasuk manusia, dana, dan kemampuan organisasional yang dilakukan oleh pemerintah maupun swasta (individu atau kelompok). Proses tersebut dilakukan untuk mencapai tujuan yang telah ditetapkan sebelumnya oleh pembuat kebijakan.

Sebuah implementasi kebijakan yang melibatkan banyak organisasi dan tingkatan birokrasi dapat dilihat dari beberapa sudut pandang. Menurut Wahab (2005:63) "implementasi kebijakan dapat dilihat dari sudut pandang (1) pembuat kebijakan, (2) pejabat-pejabat pelaksana di lapangan, dan (3) sasaran kebijakan (target group)". Perhatian utama pembuat kebijakan menurut Wahab (2005:63) memfokuskan diri pada "sejauh mana kebijakan tersebut telah tercapai dan apa alasan yang menyebabkan keberhasilan atau kegagalan kebijakan tersebut". Dari sudut pandang implementor, menurut Wahab (2005:64) implementasi akan terfokus pada "tidakan pejabat dan instansi di lapangan untuk mencapai keberhasilan program". Sementara dari sudut pandang target groups, menurut Wahab (2005:64) implementasi akan lebih dipusatkan pada "apakah implementasi kebijakan tersebut benar-benar mengubah pola hidupnya dan berdampak positif panjang bagi peningkatan mutu hidup termasuk pendapatan mereka". 


\section{e. Pelayanan Publik}

Masyarakat setiap saat selalu menuntut pelayanan publik yang berkualitas dari birokrat, meskipun tuntutan tersebut sering tidak sesuai dengan harapan karena secara empiris pelayanan publik yang ada masih bercirikan berbelit-belit, lambat, mahal, dan melelahkan.

Secara konseptual, pelayanan menurut Kotler dalam Sinambela dkk (2006:4) adalah setiap kegiatan yang menguntungkan dalam suatu kumpulan atau kesatuan, dan menawarkan kepuasan meskipun hasilnya tidak terikat pada suatu produk secara fisik. Selanjutnya Sampara berpendapat dalam Sinambela dkk (2006:5), pelayanan adalah suatu kegiatan atau urutan kegiatan yang terjadi dalam interaksi langsung antarseseorang dengan orang lain atau mesin secara fisik, dan menyediakan kepuasan pelanggan. Kemudian dalam Kamus Besar Bahasa Indonesia dijelaskan bahwa pelayanan sebagai hal, cara, atau hasil pekerjaan melayani.

Sementara itu, istilah publik berasal dari Bahasa Inggris public yang berarti umum, masyarakat, Negara. Kata publik sebenarnya sudah diterima menjadi Bahasa Indonesia Baku menjadi publik yang berarti umum, orang banyak, ramai. Padanan kata yang tepat digunakan adalah praja yang sebenarnya bermakna rakyat sehingga lahir istilah pamong praja yang berarti pemerintah yang melayani kepentingan seluruh rakyat. Inu dan kawan-kawan dalam Sinambela dkk (2006:5) mendefinisikan publik adalah sejumlah manusia yang memiliki kebersamaan berpikir, perasaan, harapan, sikap dan tindakan yang benar dan baik berdasarkan nilai-nilai norma yang merasa memiliki.

Oleh karena itu, Sinambela dan kawan-kawan mengartikan pelayanan publik sebagai kegiatan yang dilakukan oleh pemerintah terhadap sejumlah manusia yang memiliki setiap kegiatan yang menguntungkan dalam suatu kumpulan atau kesatuan, dan menawarkan kepuasan meskipun hasilnya tidak terikat pada suatu produk secara fisik.

Menurut Undang-Undang No 25 tahun 2009 tentang Pelayanan Publik, pelayanan publik adalah kegiatan atau rangkaian kegiatan dalam rangka pemenuhan kebutuhan pelayanan sesuai dengan peraturan perundang-undangan bagi setiap warga negara dan penduduk atas barang, jasa, dan atau pelayanan administratif yang disediakan oleh penyelenggara pelayanan publik.

Berdasarkan definisi diatas, dapat ditarik kesimpulan bahwa pelayanan publik adalah serangkaian kegiatan yang dilakukan dalam rangka pemenuhan kebutuhan akan pelayanan yang menawarkan kepuasan bagi setiap warga negara yang disediakan oleh penyelenggara pelayanan publik.

Pelayanan publik adalah salah satu tugas utama pemerintah yaitu untuk melayani warga masyarakatnya, dasar terselenggaranya pelayanan public itu sendiri terwujud pada salah satu Undang-Undang yang berlaku di Indonesia yaitu Undang-Undang Nomor 25 Tahun 2009 tentang Pelayanan Publik. Undang-Undang diatas yang menjadi dasar utama bagi peneliti dalam menganalisis arti penting pelayanan public khususnya aspek aksesibilitas transportasi publik pada moda transportasi Bus Rapid Transit di Kota Mataram.

\section{Metode Penelitian}

Dalam penelitian ini pendekatan yang dilakukan adalah melalui pendekatan kualitatif. Artinya data yang dikumpulkan bukan berupa analisis angka-angka statistik, melainkan data tersebut berasal dari naskah wawancara, catatan lapangan, dokumen pribadi, dan dokumen resmi lainnya. Menurut David William dalam Moleong (2006:5) menulis bahwa "penelitian Kualitatif adalah penelitian yang menggunakan latar alamiah dengan maksud menafsikan fenomena yang terjadi dan dilakukan dengan jalan melibatkan berbagai metode yang ada".

Selanjutnya, masih menurut Moleong (2006:6) yang menyatakan bahwa "Penelitian kualitatif adalah penelitian yang dimaksud untuk memahami fenomena tentang apa yang dialami oleh subjek penelitian misalnya perilaku, persepsi, motivasi, tindakan, dan lain-lain, secara holistik dan dengan cara deskripsi dalam bentuk kata-kata dan bahasa, pada suatu kontek khusus yang alamiah dan dengan memanfaatkan berbagai metode alamiah". Dengan metode penelitian ini penulis merasakan cukup memudahkan dalam melaksanakan penelitian dikarenakan data yang dikumpulkan penulis bukan merupakan data analisis angka-angka statistik.

Menambahkan menurut Lincoln dan Guba dalam Moleong (2002:17), penelitian Kualitatif yaitu "penelitian yang lebih menekankan pada pengungkapan makna dan proses, latar belakang alami (natural setting) dan digunakan sebagi sumber data langsung dari peneliti sendiri sebagai instrumen kunci". Penggunaan pendekatan kualitatif dalam penelitian ini berhubungan dengan implementasi kebijakan pengoperasian bus Trans Metro Mataram, serta factor pendukung dan penghambat yang dihadapi dalam pengoperasian Bus Trans Metro Mataram di Kota Mataram. 
Penelitian kualitatif ini tidak hanya mengungkapkan peristiwa riil, tetapi lebih dari itu hasilnya diharapkan dapat mengungkapkan nilainilai tersembunyi. Selain itu penelitian ini akan lebih peka terhadap informasi yang bersifat kualitatif deskriptif dengan secara relatif berusaha mempertahankan keutuhan dari objek yang diteliti.

Menurut Faisal (2005:18) "Penelitian deskriptif yaitu sekedar untuk melukiskan atau menggambarkan (deskripsi) sejumlah variabel yang berkenaan dengan masalah dan unit yang diteliti”. Lebih lanjut Faisal (2005:20) menjelaskan bahwa "penelitian deskriptif dimaksudkan untuk explorasi dan klarifikasi mengenai suatu fenomena atau kenyataan sosial, dengan jalan mendeskripsikan sejumlah variabel yang berkenaan dengan masalah dan unit yang diteliti”.

Lokasi penelitian menurut Iskandar (2008:219) adalah situasi dan kondisi lingkungan tempat yang berkaitan dengan masalah penelitian. Moleong (2000:86) menyatakan bahwa dalam penentuan lokasi penelitian cara terbaik yang ditempuh dengan jalan mempertimbangkan teori substantive dan menjajaki lapangan untuk mencari kesesuaian dengan kenyataan yang ada di lapangan, sementara itu keterbatasan geografis dan praktis seperti waktu, biaya dan tenaga perlu juga dijadikan pertimbangan dalam penentuan lokasi penelitian.

Guna memperoleh data, penelitian ini dilakukan pada Dinas Perhubungan Kota Mataram dan Kantor Cabang Perum Damri Mataram yang akan dilakukan pada Bulan Mei sampai dengan selesai. Dipilihnya lokasi ini karena dirasa dapat memberikan informasi yang akurat mengenai implementasi kebijakan pengoperasian Bus Trans Mataram Metro di Kota Mataram,

Dalam penelitian ini, peneliti juga menggunakan teknik snowball sampling atau teknik bola salju. Menurut Sutopo (2002:370) menyatakan bahwa "Penelitian yang menggunakan teknik snowball sampling yaitu penelitian tanpa rencana, mengorek informasi kepada informan satu yang kemudian menunjukkan informan kedua dan demikian juga dengan informan kedua menunjukkan informan ketiga terus sampai dirasa informasi yang diperoleh lengkap dan mendalam". Snowball Sampling ini dilakukan untuk melengkapi informasi yang ada sehingga dalam proses pengumpulan data, peneliti tidak membatasi jumlah informan dan lebih memilih informan yang mengetahui masalah secara mendetil.

Adapun yang menjadi informan dalam penelitian ini adalah Kepala Dinas Perhubungan Kota Mataram, Pegawai Dishub Kota Mataram,
Ketua Kantor Cabang Perum Damri Mataram Selaku Pengoperasian dan Pengelola Bus Trans Matram Metro dan masyarakat pengguna bus trans Mataram Metro, serta informan lain yang di anggap mempunyai hasil mendetil.

Dalam penelitian ini data yang dikumpulkan ada dua macam yaitu:

\section{a. Data Primer}

Menurut Indriantoro dan Supomo (2002:146) "data primer merupakan sumber data penelitian yang diperoleh secara langsung dari sumber asli (tidak melalui media prantara)". Yang menjadi data primer dalam penelitian ini adalah hasil wawancara peneliti dengan informan secara langsung.

\section{b. Data Sekunder}

Menurut Indriantoro dan Supomo (2002:147) data sekunder merupakan "sumber data penelitian yang diperoleh secara tidak langsung melalui media prerantara (diperoleh dan dicatat oleh pihak lain)". Yang menjadi data skunder yaitu terdiri dari surat kabar, undang-undang yang menyangkut dengan pelayanan, buku daftar tamu dan lain-lainnya.

Menurut Lofland dan Lofland (1984:47) sumber data utama dalam penelitian kualitatif ialah kata-kata, dan tindakan, selebihnya adalah data tambahan seperti dokumen dan lain-lain. Kata-kata dan tindakan orang- orang yang diamati atau diwawancarai merupakan sumber data utama. Sumber data utama dicatat melalui catatan tertulis atau melalui perekaman video/audio tapes, pengambilan foto, atau film (Moleong, 2007:157).

Penelitian ini menggunakan jenis sumber data yang diperoleh secara lisan dan tertulis. Adapun teknik pengumpulan data yang digunakan dalam penelitian ini adalah sebagai berikut:

\section{Observasi}

Metode observasi adalah suatu usaha sadar untuk mengumpulkan data yang dilakukan secara sistematis dengan prosedur yang terstandar (Suharsimi Arikunto, 2010:265). Observasi merupakan bentuk penerimaan data yang dilakukan dengan cara pengamatan kejadian dan pencatatan dengan sistematis terhadap fenomena-fenomena yang diteliti. Observasi bukan hanya menentukan siapa yang akan diwawancara melainkan juga menetapkan konteks, kejadian, dan prosesnya.

\section{Wawancara}

Wawancara adalah cara menghimpun bahan keterangan yang dilakukan dengan tanya jawab secara lisan secara sepihak berhadapan muka, dan dengan arah serta tujuan yang telah ditetapkan. 
Sudijono (1996:82) ada beberapa kelebihan pengumpulan data melalui wawancara, diantaranya pewawancara dapat melakukan kontak langsung dengan peserta yang akan dinilai, data diperoleh secara mendalam, yang diinterview bisa mengungkapkan isi hatinya secara lebih luas, pertanyaan yang tidak jelas bisa diulang dan diarahkan yang lebih bermakna.

\section{Dokumentasi}

Arikunto (2002:206) metode dokumentasi adalah mencari data yang berupa catatan, transkrip, buku, surat kabar, majalah, prasasti, notulen rapat, legger, agenda dan sebagainya. Nawawi (2005:133) menyatakan bahwa studi dokumentasi adalah cara pengumpulan data melalui peninggalan tertulis terutama berupa arsip-arsip dan termasuk juga buku mengenai pendapat, dalil yang berhubungan dengan masalah penyelidikan.

Secara persial prosedur analisis data dalam penelitian ini menggunanakan model analisis data dari Milles dan Huberman (2000:15-21) yaitu analisis interaktif dengan langkah-langkah sebagai berikut:

1. Pengumpulan informasi melalui wawancara terhadap key informan yang compatible terhadap penelitian kemudian observasi langsung kelapangan untuk menunjang penelitian yang dilakukan agar mendapat sumber data yang diharapkan.

2. Reduksi Data yaitu proses pemilihan proses pemusatan perhatian pada penyederhanaan, transformasi data kasar yang muncul dari catatan-catatan dilapangan selama penelitian tujuan diadakan transkip data (tansformasi data) untuk memilih transformasi data yang sesuai dengan masalah yang terjadi pusat penelitian lapangan.

3. Penyajian data (data display) yaitu kegiatan sekumpulan informasi dalam bentuk teks naratif dan tabel yang bertujuan mempertajam pemahaman penelitian terhadap informasi yang dipilih kemudian disajikan dalam tabel atau uraian penjelasan. Penyajian data atau display data dimaksudkan agar memudahkan bagi peneliti untuk melihat gambaran secara keseluruhan atau bagian-bagian tertentu dari penelitian.

4. Menarik Kesimpulan (verifikasi) yaitu mencari arti pola-pola penjelasan, konfigurasi yang mungkin, alur sebab-akibat dan proposisi. Verifikasi dalam data penelitian kulitatif ini dilakukan secara terus-menerus sepanjang proses penelitian berlangsung sejak awal memasuki lapangan dan selama proses pengumpulan data, peneliti berusaha untuk menganalisis dan mencari makna dari data yang dikumpulkan.

Agar data yang diperoleh dijamin keabsahannya sehingga dapat dipertanggung jawabkan hasil penelitiannya, maka perlu melakukan triangulasi. Menurut Moleong (2011:330) "Triangulasi adalah teknik pemeriksaan keabsahan data yang memanfaatkan sesuatu yang lain diluar data itu untuk keperluan pengecekan atau sebagai penanding untuk data itu”. Menurut Danzim dalam Moleong (2011:330) membedakan "empat macam Triangulasi sebagai teknik pemeriksaan keabsahan data yang memanfaatkan penggunaan sumber, metode, penyidik, dan teori",.

Pada penelitian ini peneliti menggunakan Triangulasi dengan penggunaan sumber. Menurut Patton dalam Moleong (2011:330) menyebutkan bahwa triangulasi dengan sumber berarti membandingkan dan mengecek balik erajat kepercayaan suatu informasi yang diperoleh melalui waktu dan alat yang membedakan dalam penelitian kualitatif'. Pengecekan keabsahan data dengan sumber menurut Moleong (2011:331) dapat diketahui dengan cara:

a. Membandingkan data hasil pengamatan dengan data hasil wawancara

b. Membandingkan apa yang dikatakan orang didepan umum dan apa yang dikatakan orang secara pribadi

c. Membandingkan dengan apa yang dikatakan orang-orang tentang situasi penelitian dengan apa yang dikatakannya sepanjang waktu

d. Membandingkan keadaan dengan persfektif seseorang dengan berbagai pendapat dan pandangan orang seperti rakyat biasa, orang yang berpendidikan menengah atau tinggi, orang berada, orang pemerintahan

e. Membandingkan hasil wawancara dengan isi suatu dokumen yang berkaitan

Dalam penelitian ini untuk mengecek keabsahan data, peneliti lebih memfokuskan kepada membandingkan data hasil pengamatan dengan data hasil wawancara.

\section{Hasil dan Pembahasan}

\section{a. Implementasi Kebijakan Pengoperasian Bus Trans Mataram Metro Di Kota Mataram}

Menurut pakar ilmu kebijakan publik Edward III tahapan penting siklus kebijakan publik adalah implementasi kebijakan. Implementasi sering dianggap hanya merupakan pelaksanaan dari apa 
yang telah diputuskan oleh legislative atau para pengambil keputusan, seolah-olah tahapan ini kurang berpengaruh. Akan tetapi dalam kenyataannya, tahapan implementasi menjadi begitu penting kerena suatu kebijakan tidak akan berarti apa-apa jika tidak dapat dilaksanakan dengan baik dan benar. Dengan kata lain implementasi merupakan tahap dimana suatu kebijakan dilaksanakan secara maksimal dan dapat mencapai tujuan kebijakan itu sendiri.

Dalam lingkup wilayah Kota Mataram pemerintah daerah telah mengeluarkan kebijakan berupa Peraturan Daerah yang mengatur tentang penyelenggaraan perhubungan dalam lingkup Kota Mataram. Karena Peraturan Daerah tersebut telah di tetapkan dan disahkan dan diberlakukan maka kebijakan tersebut harus diterapakan untuk mencapai tujuan utama Peraturan Daerah tersebut dibuat. Penulis menggunakan teori Edward III dalam melihat Implementasi Kebijakan Pengoperasian Bus Trans Mataram Metro di Kota Mataram. Edward III menjelaskan bahwa ada empat varaibel yang menjadi indikator keberhasilan pengimplementasian suatu kebijakan publik yaitu komunikasi, sumber daya, struktur birokrasi dan disposisi.

Berikut ini penulis akan membrikan uraian mengenai pengimplementasian Pengoperasian Bus Trans Mataram Metro di Kota Mataram.

\section{a. Komunikasi}

Komunikasi merupakan proses penyampaian informasi dari komunikator kepada komunikan. Sementara itu, komunikasi kebijakan berarti merupakan proses penyampaian informasi kebijakan dari pembuat kebijakan (policy makers) kepada pelaksana kebijakan (policy implementors).

Dalam komunikasi yang terpenting adalah akses informasi, dalam rangka akses informasi. Pemerintahan Daerah wajib menyebarluaskan rancangan atau peraturan perundang-undangan tingkat daerah. Penyebarluasan bagi Peraturan Daerah dan Peraturan perundang-undangan dibawahnya dilakukan sesuai dengan perintah Pasal 94 Undang Undang Nomor 12 Tahun 2011 tentang Pembentukan Peraturan perundang-undangan yang menyatakan bahwa: Penyebarluasan Peraturan Daerah Provinsi atau Peraturan Daerah Kabupaten/Kota yang telah dituangkan dalam Lembaran Daerah dilakukan bersama oleh DPRD dan Pemerintah Daerah Provinsi atau Kabupaten/Kota. Penyebarluasan dimaksudkan agar khalayak ramai mengetahui Peraturan Perundangundangan di daerah yang bersangkutan dan mengerti/memahami isi serta maksud yang terkandung di dalamnya. Penyebarluasan dapat dilakukan melalui media elektronik, atau media cetak yang terbit di daerah yang bersangkutan serta media komunikasi langsung. Jadi suatu produk hukum daerah berupa Peraturan Daerah seharusnya diketahui dan dipahami oleh seluruh komponen yang terkait didalamnya.

Untuk mengukur sejauh mana keefektifan komunikasi kebijakan pengoperasian Bus Trans Mataram Metro di Kota Mataram dapat kita lihat pada dimensi berikut:

\section{Transmisi}

Dimensi transformasi menghendaki agar informasi tidak hanya disampaikan kepada pelaksana kebijakan tetapi juga kepada kelompok sasaran dan pihak yang terkait yang berkepentingan baik secara langsung maupun tidak langsung. Kebijakan Pengoperasian Bus Trans Mataram Metro telah disosialisasikan kepada pihak terkait, karena dalam penyelenggarannya ini melalui proses yang panjang dimulai dari perizinan pengadaan serta rancangan dimana Pemerintah Pusat memberikan tanggung jawab kepada Dinas Perhubungan Kota Mataram sebagai pelaksana, kemudian diserahkan kepada Perum Damri Kota Mataram sebagai pengelola dalam pengoperasian Bus Trans Mataram Metro di Kota Mataram. Melalui penjelasan ini kita dapat menyimpulkan bahwa proses penyelenggaraan Bus Trans Mataram Metro melalui beberapa proses perizinan sampai pada tahap pengadaan melalui beberapa tahap yang panjang sehingga tidak ada alasan lagi bagi instansi terkait untuk tidak mengetahui dan memahami maksud dan tujuan dalam penyelenggaraan Bus Trans Mataram Metro di Kota Mataram.

Sosialisasi Pengoperasian Bus Trans Mataram Metro ditingkat pelaksana atau implementor ini telah dilakukan oleh Pemerintah Pusat pada tanggal 21 November 2016 melalui media massa yaitu melalui Tempo.co yang di dalamnya berisikan informasi mengenai Sebanyak 25 unit bus rapid transit (BRT) mulai diopesikan di Mataram. Sebagai awal pengoperasian, selama 45 hari digratiskan bagi pelajar saat jam berangkat dan jam pulang sekolah. Di luar jam tersebut, termasuk penumpang umum, dikenai ongkos jauh-dekat Rp 4000 per orang.

Sedangkan sosialisasi Pengoperasian Bus Trans Mataram Metro kepada kelompok sasaran atau masyarakat Kota Mataram khususnya pengguna angkutan umum, juga disosialisasikan langsung oleh aparat Dinas Perhubungan Kota Mataram.

\section{Dimensi Kejelasan Informasi}


Dimensi kejelasan menghendaki agar informasi yang jelas dan mudah dipahami, selain itu menghindari kesalahan interpretasi dari pelaksana kebijakan, kelompok sasaran maupun pihak yang terkait dalam implementasi kebijakan. Pengoperasian Bus Trans Mataram Metro di Kota Mataram yang bertujuan untuk menyelesaikan masalah yang ada di jalan-jalan Kota seperti kemacetan dan tingginya penggunaan kendaraan pribadi yang mengakibatkan penuhnya ruas jalan bagi pengguna jalan, jadi seluruh upaya yang dilakukan implementor adalah bagaimana meminimalisir penggunaan kendaraan pribadi agar tidak mengakibatkan kemacetan.

\section{Konsistensi Informasi}

Dimensi konsistensi menghendaki agar informasi yang disampaikan harus konsisten sehingga tidak menimbulkan kebingungan pelaksana kebijakan, kelompok sasaran maupun pihak terkait.

Informasi mengenai pengoperasian Bus Trans Mataram Metro adalah untuk mengurangi kemacetan dan penggunaan kendaraaan pribadi. Pelaksanaan kebijakan, kelompok sasaran, dan pihak terkait sudah mengetahui maksud tujuan pengoperasian tersebut.

Masyarakat telah mengetahui dan mengerti mengenai Pengoperasian Bus Trans Mataram Metro tersebut.

\section{b. Sumber Daya}

Sumber daya memiliki peranan penting dalam implementasi kebijakan bagaimanapun jelas dan konsistensinya ketentuan-ketentuan dan aturanaturan serta bagaimanapun akuratnya penyampaian ketentuan-ketentuan atau aturan-aturan tersebut, jika para pelaksana kebijakan yang bertanggung jawab untuk melaksanakan kebijakan kurang mempunyai sumber-sumber daya untuk melaksanakan kebijakan secara efektif maka implementasi kebijakan tersebut tidak akan efektif.

Sebagai daerah otonom Kota Mataram tentunya mempunyai sumber daya untuk mengimplementasikan kebijakan yang telah dibuat termasuk dalam mengimplementasikan Pembangunan Daerah sebagai suatu tahapan pembangunan daerah. Sumberdaya di sini berkaitan dengan segala sumber yang dapat digunakan untuk mendukung keberhasilan implementasi kebijakan. Sumber daya ini mencakup sumber daya manusia, anggaran, fasilitas, informasi dan kewenangan yang dijelaskan sebagai berikut:

\section{Sumber Daya Manusia}

Implementasi kebijakan tidak akan berhasil tanpa adanya dukungan dari sumber daya manusia yang cukup kualitas dan kuantitasnya. Kualitas sumber daya manusia berkaitan dengan keterampilan, dedikas, profesionalitas, dan kompetensi di bidangnya, sedangkan kuatitas berkaitan dengan jumlah sumber daya manusia apakah sudah cukup untuk melingkupi seluruh kelompok sasaran. Sumber daya manusia sangat berpengaruh terhadap keberhasilan implementasi, sebab tanpa sumber daya manusia yang kehandalan sumber daya manusia, implementasi kebijakan akan berjalan lambat.

\section{Staf dan Skill}

Sumber daya manusia berkaitan dengan staf atau aparat pelaksana apakah sudah cukup tersedia atau perlu adanya penambahan staf implementor kebijakan. Ketersediaan jumlah staf yang cukup menjadi faktor penentu suatu kebijakan. Kegagalan yang sering terjadi dalam implementasi kebijakan salah satunya disebabkan oleh karena staf yang tidak mencukupi, memadai, ataupun tidak kompeten di bidangngya. Namun jumlah staf yang memadai belum menjamin keberhasilan implementasi suatu kebijakan, staf harus mempunyai keterampilan dan kompentensi dibidangnya masing-masing.

\section{Sumber Daya Anggaran}

Dalam implementasi kebijakan, anggaran berkaitan dengan kecukupan modal atau investasi atas suatu program atau kebijakan untuk menjamin terlaksananya kebijakan, sebab tanpa dukungan anggaran yang memadahi, kebijakan tidak akan berjalan dengan efektif dalam mencapai tujuan dan sasaran.

Sementara itu dalam mengimplementasikan kebijakan pengoperasian Bus Trans Mataram Metro di Kota Mataram. Jumlah Anggaran mengalami penurunan di setiap tahun pengoperasiannya tidak ada dukungan dari anggaran khusus yang dianggarkan dalam APBD Kota Mataram. Seluruh biaya yang digunakan dalam penegakan pengoperasiannya ini hanya dialokasikan melalui anggaran operasional badan atau instansi terkait sehubungan dengan itu berikut hasil wawancara penulis dengan bapak H. Lalu Wirajaya, ST. M.Si sebagai kepala bidang angkutan di Dinas Perhubungan Kota Mataram, beliau mengatakan:

"kalo kita mengoperasikan 4 bus saja anggarannya untuk 1 tahun kurang lebih sebesar 10 Miliyar ini sebenarnya Damri tidak sanggup mengoperasikan, karena Damri istilahnya punya BUMN, jadi mereka itu profit riented, jadi kalo mereka jalan tanpa ada profit bias-bisa BRT akan diberhentikan. Itulah permasalahannya karena biaya operasionalnya 
besar jadi tidak sanggup mengoperasikan. Dukungan dari kita juga mungkin anggaran 10 Miliyar terlalu berat termasuk provinsi". (Wawancara, 08 Juli 2019).

Senada dengan hal itu pihak Damri membenarkan bahwa tidak ada anggaran khusus untuk mengoperasikan Bus Trans Mataram ini. Namun karena kurangnya anggaran maka Bus Trans Mataram Metro jarang dioperasikan dengan alasan tidak adanya biaya operasional.

\section{c. Disposisi}

Disposisi atau sikap adalah suatu perilaku yang ditunjukkan oleh elemen-elemen dari suatu kegiatan implementasi kebijakan untuk mampu menyelaraskan adanya penumbuhan perilaku dari sikap yang ditunjukkan oleh para pengembang kebijakan pemerintah pada subyek dan obyek kebijakan. Termasuk di dalamnya berbagai bentuk program kegiatan dan tindak lanjut dari suatu kegiatan pembangunan.

Kecenderungan perilaku atau karakteristik dari pelaksana kebijakan berperan penting untuk mewujudkan implementasi kebijakan yang sesuai dengan tujuan atau sasaran. Karakter penting yang harus dimiliki oleh pelaksana kebijakan misalnya kejujuran dan komitmen yang tinggi. Kejujuran mengarahkan implementor untuk tetap berada dalam masa program yang telah digariskan, sedangkan komitmen yang tinggi dari pelaksana kebijakan akan mereka selalu antusias dalam melaksanakan tugas, wewenang, fungsi, dan tanggung jawab sesuai dengan peraturan yang telah ditetapkan.

Dalam hal implementasi pengoperasian Bus Trans Mataram Metro di Kota Mataram, disposisi atau sikap implementor belum seutuhnya mendukung dan menjalankan tupoksinya dengan baik. Sangat jelas bahwa Dinas Perhubungan Kota Mataram sebagai pelaksana penyelenggara beroperasinya Bus Trans Mataram Metro tersebut dibantu oleh Damri sebagai selaku pengelola Bus Trans Mataram Metro.

Sejauh ini selama beroperasinya Bus Trans Mataram Metro ini diadakan dan dioperasikan pada tahun 2016 sampai sekarang (tahun 2019), pengoperasian Bus Trans Mataram Metro ini belum maksimal dikaranakan pihak pelaksana hanya turun langsung kelapangan secara insidentil. Tidak adanya waktu tertentu yang ditetapkan untuk melakukan sosialisasi, pengecekan, dan pengarahan kepada masyarakat memunculkan indikasi bahwa aparat pelaksana masih pragmatis dalam mengoperasikan Bus Trans Mataram Metro tersebut.
Adapun hasil wawancara dengan Bapak Lalu Wirajaya, ST. M.Si, yang berkaitan dengan sikap disposisi pelaksana implementor di Kota Mataram belum efektif sesuai petikan wawancara berikut ini: "Dari kami sendiri belum disiapkannya bentuk kelembagaan yang akan mengelola dan mengendalikan pengoperasian serta pengembangan sistem angkutan massal ini, yang secara khusus menangani Bus Trans Mataram karena kurangnya minat dari masyarakat dalam mendukung perkembangan moda transportasi public di Kota Mataram.”. (Wawancara, 08 Juli 2019).

\section{d. Struktur Birokrasi}

Struktur birokrasi memiliki pengaruh yang signifikan terhadap implementasi kebijakan. Aspek struktur organisasi ini melingkupi dua hal yaitu mekanisme dan struktur birokrasi itu sendiri. Aspek pertama adalah mekanisme, dalam implementasi kebijakan biasanya sudah dibuat standart operation procedure (SOP). SOP menjadi pedoman bagi setiap implementor dalam bertindak agar dalam pelaksanaan kebijakan tidak melenceng dari tujuan dan sasaran kebijakan. Aspek kedua adalah struktur birokrasi, struktur birokrasi yang teralalu panjang dan terfragmentasi akan cenderung melemahkan pengawasan dan menyebabkan prosedur birokrasi yang rumit dan kompleks yang selanjutnya akan menyebabkan aktivitas organisasi menjadi tidak fleksibel.

Kebijakan pengoperasian Bus Trans Mataram Metro merupakan suatu penyelenggaraan pembangunan Nasional yang mempunyai prosedur dan standar operasional agar kebijakannya terlaksana sesuai dengan tujuan yang telah ditetapkan.

Berdasarkan isi penjelasan Peraturan Daerah No 7 Tahun 2016 Tentang penyelenggaraan perhubungan, maka sturktur birokrasi dalam mengimplementasikan kebijakan pengoperasian Bus Trans Mataram Metro tersebut, maka dapat dilihat uraian sebagai berikut:

Dalam rangka menunjang perkembangan pembangunan dan pertumbuhan perekonomian di Kota Mataram, diperlukan sistem lalu lintas dan angkutan jalan yang lancar, tertib, aman, nyaman, berdaya guna dan berhasil guna. Dimana, penyelenggaraan Lalu Lintas dan Angkutan Jalan mempunyai peran strategis dalam mendukung pembangunan daerah dan sebagai bagian dari upaya memajukan kesejahteraan masyarakat, penyelenggaraan pemerintahan, dan meningkatkan pelayanan kepada masyarakat, serta kemandirian daerah berdasarkan prinsip demokrasi, pemerataan dan keadilan, peran 
serta masyarakat, dan akuntabilitas dengan memperhatikan potensi daerah. Maka, Lalu Lintas dan Angkutan Jalan sebagai bagian dari sistem transportasi harus dikembangkan potensi dan perannya untuk mewujudkan keamanan, keselamatan, ketertiban, dan kelancaran berlalu lintas dan Angkutan Jalan.

Selain itu, sistem lalu lintas dan angkutan jalan perlu diselenggarakan dengan mengintergrasikan semua komponen lalu lintas dan angkutan jalan ke dalam satu kesatuan yang mencakup seluruh kebijaksanaan Pemerintah Daerah berdasarkan kewenangannya sesuai Undang-Undang Nomor 23 Tahun 2014 tentang Pemerintahan Daerah. Maka untuk mewujudkan hal tersebut, perlu adanya koordinasi antara stakeholders, instansi terkait dilingkungan Pemerintah Kota Mataram, maupun antara Pemerintah, Pemerintah Daerah, Kepolisian, Pihak terkait dan adanya peran serta masyarakat, sehingga tercapai keseimbangan antara pembangunan fisik daerah dengan pembangunan sektor transportasi yang bermanfaat bagi masyarakat.

Pengaturan operasional lalu lintas dan angkutan jalan di Kota Mataram yang selama ini kurang menunjukkan efektifitas dan efisiensi kinerja, sehingga perlu diadakan penyesuaian dengan mengunifikasikan keseluruhan peraturan perundang-undangan tentang lalu lintas dan angkutan jalan ke dalam satu Peraturan Daerah tentang Penyelenggaraan Perhubungan.

Dalam Peraturan Daerah No 7 Tahun 2016 Tentang Penyelenggaraan Perhubungan manggambarkan struktur birokrasi yang jelas akan tetapi menurut pengamatan penulis dilapangan bahwa instansi yang terkait belum menjalankan tugas dan fugsinya sebagaimana mestinya.

\section{e. Kontribusi Dinas Perhubungan Kota Mataram}

Dalam upayanya untuk meningkatkan pelayanan mesyarakat di bidang angkutan kota di Kota Mataram maka Dishub Kota Mataram diharuskan untuk memaksimalkan perannya yakni sebagai pembuat kebijakan (regulator), penyedia fasilitas (fasilitator) dan sebagai pengawas (evaluator). Sebab sebagaimana sasaran yang ingin dicapai oleh Dishub Kota Mataram adalah terciptanya pelayanan transportasi yang efektif, dalam arti aksesibilitas tinggi, terpadu, kapasitas mencukupi, tarif terjangkau, tertib, teratur, lancar dan cepat, selamat, aman, mudah, tepat waktu dan nyaman, serta efisien dalam kesatuan jaringan Transportasi Nasional ( Dinas Perhubungan Kota Mataram).

\section{1) Dishub Sebagai Pembuat Kebijakan (Regulator) Dalam Upaya Peningkatan Pelayanan Masyarakat Di Bidang Angkuta Kota Di Kota Mataram}

Begitu besar pentingnya moda transportasi umum ini Dishub Kota Mataram sebagai salah satu dinas pemerintah yang bertugas untuk mengatur lalu lintas dan angkutan diberikan kewenangan untuk membuat suatu aturan atau kebijakan yang nantinya dapat memberikan kepuasan pelayanan kepada masyarakat. Aturan tersebut diantaranya adalah (1) Menetapkan jalur trayek angkutan kota, di mana terdapat 4 jalur trayek angkutan kota di Kota Mataram, (2) Penetapan tarif, dimana untuk penumpang umum dikenakan tarif $\mathrm{Rp} 4000$ dan untuk pelajar gratis, (3) Penetapan waktu beroperasi angkutan kota yakni dimulai pagi hari pukul 05.00 dan berakhir malam hari pukul 21.00, (4) Ketentuan Uji KIR.

2) Dishub Sebagai Penyedia Fasilitas (Fasilitator) Dalam Upaya-Upaya Peningkatan Pelayanan Masyarakat Bidang Angkutan Kota Di Kota Mataram

Dishub Kota Mataram memberikan fasilitasfasilitas penunjang pelayanan angkutan kota kepada semua lapisan masyarakat tanpa membedakan status ataupun jenis kelamin, sehingga akan tercipta pelayanan yang adil yang dirasakan oleh penerima pelayanan yaitu masyarakat Kota Mataram. Hal tersebut meliputi (1) Menyediakan unit-unit angkutan kota dimana banyaknya kendaraan angkutan kota yang beroperasi di Kota Mataram, (2) Menyediakan sarana dan prasarana, yakni berupa terminal dan sub-terminal serta halte.

3) Dishub Sebagai Pengawas (Evaluator) Dalam Upaya-Upaya Peningkatan Pelayanan Masyarakat Bidang Angkutan Kota Di Kota Mataram

Dishub Kota Mataram sebagai Dinas yang mengatur lalu lintas dan angkutan jalan harus dapat menjadi pengawas agar tujuan dan sasaran dapat terlaksana dengan baik sesuai dengan rencana. Berikut merupakan wewenang Dishub Kota Mataram sebagai pengawas bidang angkutan, meliputi (1) pengawasan terhadap pelaksaan izin usaha angkutan dan izin trayek (2) Pengawasan terhadap kelayakan kendaraan bermotor umum (3) Pengawasan kesesuaian jalur angkutan kota (4) Pengawasan kesesuaian tarif (5) Penyidikan terhadap kelebihan muatan

\section{f. Terpenuhi Tidaknya Pemasukan Dengan Biaya Operasional}


Dalam penyelenggaraan Bus Trans Mataram Metro di Kota Mataram mengalami masalah dalam hal anggaran, tidak terlaksananya anggaran yang dikeluarkan Dishub NTB, Pemkab Lombok Barat dan Dishub Kota Mataram akibat peralihannya anggaran untuk penanganan pasca gempa. telah di jelasakan pada bab sebelumnya maka penulis Berdasarkan hasil wawancara peneliti dengan salah menarik kesimpulan sesuai dengan permasalahan satu staf Dinas Perhubungan Kota Mataram, Berikut yang diteliti yaitu Implementasi Kebijakan hasil wawancara:

Pengoperasian Bus Trans Mataram Metro Di Kota

" Kalau 2019 kita tidak pernah menganggarkan Mataram adalah sebagai berikut:

untuk BRT. Tahun 2018 itu dianggarkan oleh Dari hasil Pelitian dilapangan penulis Dishub Provinsi NTB yang Rp 500 juta. Makanya mengambil kesimpulan bahwa kebijakan sempat beberapa kali jalan. Saya belum tahu dan pengoperasian Bus Trans Mataram belum berjalan belum dapat informasi apakah provinsi efektif dan masih terdapat kendala dalam menganggarkan itu pada tahun ini".(Wawancara, implementasinya yang masih harus diperbaiki. 08 Agustus 2019).

e. Faktor Pendukung Dan Penghambat Pengoperasian Bus Trans Mataram Metro di Kota Implementasi Kebijakan Pengoperasian Bus Mataram belum berjalan efektif adalah sebagai Trans Mataram Metro Di Kota Mataram

Adapun faktor pendukung dan penghambat implementasi pengoperasian Bus Trans Mataram Metro Di Kota Mataram adalah sebagai berikut:

\section{1) Faktor Pendukung}

Dalam Pelaksanaan Bus Trans Mataram Metro di Kota Mataram terdapat faktor pendukung dalam pengoperasiannya:

a. Membantu pada Masyarakat yang tidak memiliki akses kendaraan pribadi.

b. Adanya layanan alternative dari pemerintah.

c. Membantu masyarakat yang ekomominya rendah.

\section{2) Faktor Penghambat}

Di setiap faktor pendukung maka pasti akan ada faktor penghambat, faktor penghambat dalam implementasi kebijakan pengoperasian Bus Trans Mataram Metro di Kota Mataram meliputi ketidaktahuan masyarakat mengenai pengoperasian Bus Trans Mataram Metro di Kota Mataram sebagai moda transportasi massal. Hal ini berdasarkan hasil wawancara yang peneliti lakukan dengan Bapak Ismail Faruqi yang mengatakan bahwa:

"Masa ada Bus Trans Mataram Metro yang saya tahu cuma adanya pembangunan halte di sepanjang jalan di Kota Mataram, saya kira pembangunan halte itu sebagai tempat pemberhentian angkot, cidomo sama angkutan lain" (Wawancara, 08 Juli 2019).

Masih banyaknya masyarakat yang belum mengetahui pengoperasian Bus Trans Mataram Metro di Kota Mataram yang disebabkan pemberian informasi dari pihak pelaksana yang belum terlaksana dengan baik dan ketidaksanggupan berikut:

a. Komunikasi, belum maksimalnya sosialisasi yang dilakukan sehingga baik aparat pelaksana maupun masyarakat belum mengetahui tugas, fungsi dan perannya masing-masing.

b. Sumber daya, berdasarkan pengamatan penulis bahwa sumber daya dan perangkat organisasi implementor sudah memadai namun belum maksimal dari segi pelaksanaanya.

c. Disposisi, hal ini berkaitan dengan sikap dan konsistensi implementor yang terkesan mengabaikan kebijakan tersebut. Sehingga pelaksanaan pengoperasian Bus Trans Mataram Metro belum continue dan berkelanjutan.

d. Struktur birokrasi, instansi yang terkait dalam mengimplementasikan pengoperasian Bus Trans Mataram Metro serta alur dan mekanismenya sudah jelas dalam Perda, namun implementor belum bisa berperan sesuai tugas, fungsi dan tanggung jawabnya. Masih ada tumpang tindih pada wilayah kerja masing-masing instansi pelaksana.

1. Faktor Pendukung dan Penghambat

a. Faktor Pendukung

Adapun faktor pendukung Pengoprasian Bus trans Mataram Metro di Kota Mataram adalah sebagai berikut:

1) Membantu pada masyarakat yang tidak memiliki akses kendaraan pribadi.

2) Adanya layanan alternative dari pemerintah.

3) Membantu masyarakat ekonomi rendah.

b. Faktor Penghambat

Adapun faktor penghambat dalam Pengoprasian Busa Trans Mataram Metro di Kota mataram seperti, ketidak tahuan 
Masyarakat mengenai pengoprasian Bis Trans Mataram Metro di Kota Mataram sebagai Moda Transportasi Massal.

Sedangkan untuk indikatornya sebagai berikut:

1) Untuk Biaya Operasional bagi Bus Trans Mataram Metro di butuhkan pengeluaran yang sangat besar bagi pelaksanaan kebijakan pengoperasian Bus Trans Mataram Metro di Kota Mataram Metro tersebut.

2) Jumlah Penumpang. Berdasarkan pengamatan penulis jumlah penumpang per koridor mengalami penurunan.

3) Kualitas Pelayanan. Dari pengamatan penilis terhadap pelayanan masih belum memenuhi stantar pelayanan yang baik

4) Kurangnya sosialisasi yang dilakukan pihak pelaksana

\section{Saran}

Berdasarkan kesimpulan yang penulis uraikan diatas maka dapat direkomendasikan saran-saran sebagai berikut:

a. Pemerintah Kota Mataram melalui instansi yang terkait dengan Perda tersebut harus konsisten dalam menjalankan dan memberikan pelayanan sesuai dengan isi Perda No 7 Tahun 2016 Tentang Penyelenggaraan Perhubungan tersebut agar berjalan sesuai semesrinya.

b. Pengguna menggunakan fasilitas layanan dari pemerintah, guna mempermudah dan memperlancar aktivitas ekonomi, sosial, budaya, bahkan agama.

c. Diharapkan kepada masyarakat sebagai kelompok sasaran dari Kebijakan pengoperasian Bus Trans Mataram Metro untuk ikut berperan mematuhi dan mengamalkan demi menciptakan Kota Mataram yang maju, religius dan berbudaya.

d. Perlu dilakukan sosialisasi yang luas guna memperbaiki informasi serta layanan Bus Trans Mataram Metro.

e. Bus Trans Mataram Metro ini membantu mengurangi kemacetan pada jam kerja karena banyaknya kendaraan pribadi.

\section{Daftar Pustaka}

[1] Abdul Wahab, Solichin. 2005. Analisis Kebijaksanaan dari Formulasi ke Implementasi Kebijaksanaan Negara. Jakarta: Bumi Aksara.

[2] Agustinus, Leo. 2006. Politik dan Kebijakan Publik. Bandung: AIPI.
[3] Arikunto, Suharsimi. 2002. Prosedur Penelitian Suatu Pendekatan Praktek. Jakarta: PT. Rineka Cipta.

[4] . 2010. Prosedur Penelitian Suatu Pendekatan Praktek. Jakarta: PT. Rineka Cipta.

[5] Duarte. 2012. Bus Rapid Transit (BRT), Alat transportasi massal.

[6] Dunn, William N. 2000. Pengantar Analisa Kebijakan Publik. Yogyakarta: Gajah Mada University Press.

[7] Faisal. 2005. "Analisis Agency Costs, Stuktur Kepemilikan dan Mekanisme Corporate Governance”. Jurnal Riset Akutansi Indonesia, Vol. 8, No. 2, Mei 2005, hal. 175-190

[8] H.B, Sutopo. 2002. Metodologi Penelitian Kualitatif. Surakarta: UNS Press.

[9]_ 2006. Metodologi Penelitian Kualitatif. Surakarta: UNS Press.

[10] Indriantoro, Nur., dan Supomo. 2002. Metode Penelitian Bisnis untuk Akutansi dan Manajemen. Yogyakarta: BPFE.

[11] Iskandar. 2008. Metodologi Penelitian Pendidikan dan Sosial (Kuantitatif dan Kualitatif). Jakarta: GP Press.

[12] Islamy, M. Irfan. 2001. Prinsip-prinsip Perumusan Kebijakan Negara. Jakarta: Bumi Aksara.

[13] Lofland, John., Lofland, Lyn.H. 1984. Analyzing Social Settings. California: Wadsworth Publishing Company.

[14] Mentari. 2017. Implementasi Kebijakan Pengadaan Bus Sekolah Gratis Bagi Pelajar di Kecamatan Mandau Kabupaten Bengkalis. JOM FISIP, Vol. 4 No. 2.

[15] Miles, M.B., dan Huberman. 2000. Analisis Data Kualitatif. Terjemahan oleh Tjetjep Rohendi Rohadi. Jakarta: Universitas Indonesia Press.

[16] Moleong., dan J, Lexy. 2000. Metode Penelitian Kualitatif. Bandung: Remaja Rosdakarya.

[17] . 2002. Metode Penelitian Kualitatif. Bandung: Remaja Rosdakarya.

[18]

2006. Metode

Penelitian Kualitatif. Bandung: Remaja Rosdakarya.

[19] . 2007. Metode

Penelitian Kualitatif. Bandung: Remaja

Rosdakarya.

[20]

Penelitian Kualitatif. Bandung: Remaja

Rosdakarya. 
[21] Nawawi, Hadari. 2005. Penelitian Terapan. Yogyakarta: Gajah Mada University.

[22] Nugroho, Riant. 2008. Publik Policy: Teori kebijakan-Analisis Kebijakan-Proses. Jakarta: Elex Media Komputindo.

[23] Pasolong, Harbani. 2010. Teori Administrasi Publik. Bandung: Alfabeta.

[24] Rudor, Chrisgerson., dan Findi A, Muhammad. 2012. Kebijakan Perencanaan Angkutan Massal di Kota Bogor. Jurnal Ekonomi dan Kebijakan Pembangunan, hlm. 159-166, Oktober 2012, Vol.1 No.2.

[25] Sadali, dkk. 2007. Ilmu Pengetahuan Sosial Terpadu (Geografi, Sejarah, Sosiologi, dan Ekonomi). Jakarta: Bumi Aksara.

[26] Santoso, Pandji. 2009. Administrasi Publik, Teori dan Aplikasi Good Governance. Bandung: PT. Refika Aditama.

[27] Sinambela, LijanPoltak. 2006. Reformasi Pelayanan Publik: Teori, Kebijakan, dan Implementasi. Jakarta: PT. Bumi Aksara.

[28] Sudijono, Anas. 1996. Pengantar Evaluasi Pendidikan. Jakarta: PT. Raja. Grafindo Persada.

[29] Suharno. 2010. Dasar-dasar Kebijakan Publik. Yogyakarta: UNY Press.

[30] Tamin, Ofyar Z. 2000. Perencanaan dan Pemodelan Transportasi. Bandung: Penerbit ITB

[31] Widodo, Joko. 2010. Analisis Kebijakan Publik. Malang: Bayumedia.

[32] Winarno, Budi. 2007. Kebijakan Publik: Teori dan Proses. Yogyakarta: Media Presindo.

\section{Artikel/Modul/Diktat}

[1] Undang-Undang Nomor. 22 Tahun 2009 tentang lalu Lintas dan Angkutan Jalan.

[2] Crishandrix. 2013. Kemacetan dan Pola Adaptasi Pengendara di Kota Besar (Seri "parody lalu lintas jalanan"). [https://chrishandrix.wordpress.com/2013/03/18/ kemacetan-dan-pola-adaptasi-pengendara-dikota-besar/], di akses pada tanggal 04/04/2019.

[3] Firdaus, Adam. 2016. Cerminan Evaluasi Permasalahan Indonesia Sebagai Negara Berkembang.

[https://www.depokpos.com/arsip/2016/12/cermi nan-evaluasi-permasalahan-indonesia-sebagainegara-berkembang/], di akses pada tanggal 04/04/2019.

[4] Krisiyanto. 2009. Dampak Negatif Transportasi Darat Dan Penanggulangannya. [https://krizi.wordpress.com/tag/kemacetan-diindonesia/], di akses pada tanggal 04/04/2019.

[5] Sufiani, A., Alvinsyah., Hadian, E. 2016. Potensi dan Kendala Pengembangan Angkutan Umum massal di kota mataram dan Sekitarnya.[http://iutri.org/artikel/potensi-dankendala-pengembangan-angkutan-umum-masaldi-kota-mataram-dan-sekitarnya.html], diakses pada tanggal 12/04/2019.

[6] https://nasional.tempo.co/read/821876/bus-rapidtransit-mulai-beroperasi-di-kota-mataram 